\title{
Pelatihan Pemanfaatan E-commerce Bagi Peningkatan Mutu Sosial Tenaga Kerja dan Wanita di Kelurahan Rongtengah Sampang Madura
}

\author{
Ariesta Kartika Sari ${ }^{1}$, Wanda Ramansyah ${ }^{2}$, Puji Rahayu Ningsih ${ }^{3}$, \\ Medika Risnasari ${ }^{4}$, Muchamad Arif ${ }^{5}$, Sigit Dwi Saputro ${ }^{6}$, \\ Muhamad Afif Effindi ${ }^{7}$ \\ 1,2,3,4,5,6,7 Universitas Trunojoyo Madura \\ Email: ariestakartika@ trunojoyo.ac.id ${ }^{1}$
}

\begin{abstract}
ABSTRAK
Usaha Mikro Kecil dan Menengah merupakan salah satu potensi bagi pertumbuhan perekonomian negara. Seiring dengan perkembangan teknologi informasi yang memunculkan cara baru dalam memasarkan produk, tentu UMKM perlu memanfaatkan keberadaannya. Melalui kegiatan Pengabdian Masyarakat ini, Program Studi Pendidikan Informatika Universitas Trunojoyo Madura melihat adanya potensi bagi perkembangan UMKM dalam menggunakan $e$-commerce dan Marketplace bagi perkembangan ekonomi yang pada akhirnya akan didapatkan peningkatan mutu sosial tenaga kerja dan wanita. Serangkaian kegiatan pelatihan yang dilaksanakan dalam kegiatan Pengabdian Masyarakat ini menunjukkan bahwa peserta memiliki pemahaman materi dan potensi untuk mengembangkan usaha.
\end{abstract}

Kata Kunci: e-commerce, Marketplace

\begin{abstract}
Small and Medium Enterprises (SME) has important role in economic growth. Along with the advance development of information technology emerging new tools for promoting product which can be used by SME. Through Public Service, the Department of Informatics Education Universitas Trunojoyo Madura sees potential economic development for SME for using tools such as e-commerce and Marketplace which is could guide to the enhancement of social quality of women and women labor, especially in Madura. Through the Public Service, it could be concluded further development of the attendees to use and promote their SME's product.
\end{abstract}

Keywords: e-commerce, Marketplace.

\section{PENDAHULUAN}

Kamus Besar Bahasa Indonesia mengartikan Wirausaha dalam artian sama dengan Wiraswasta, yakni "orang yang pandai atau berbakat mengenali produk baru, menentukan cara produksi baru, menyusun operasi untuk pengadaan produk baru, memasarkannya, serta mengatur permodalan operasinya". Keberadaan wirausaha, dalam hal ini Usaha Mikro Kecil dan Menengah atau UMKM bagi beberapa orang masih belum didata dengan seharusnya. Hal ini berimplikasi pada asumsi bahwa UMKM belum dapat memberikan pembukaan lapangan pekerjaan secara nyata, padahal 
menurut Li dan Rama (2015) hal ini tidak sepenuhnya benar.

Tidak hanya membuka peluang lapangan pekerjaan dan kontribusinya bagi pertumbuhan ekonomi negara, keberadaan UMKM juga sangat penting saat terjadi krisis keuangan. UMKM terbukti menjadi bidang yang tahan terhadap krisis keuangan. UMKM juga menjadi fokus bahasan dalam World Islamic Economic Forum/WIEF) ke-12 yang digelar di Jakarta pada 2 - 4 Agustus 2016. Bidang wirausaha ini pula yang menjadi bidang garapan Perguruan Tinggi.

Melalui salah satu kegiatan tridharma Perguruan Tinggi, yakni Pengabdian kepada Masyarakat, perguruan tinggi diharapkan dapat memberikan kontribusi bagi perkembangan masyarakat. Salah satunya adalah Program Studi Pendidikan Informatika, Universitas Trunojoyo Madura. Dalam pelaksanan kegiatan Pengabdian kepada Masyarakat kali ini, Program Studi Pendidikan Informatika membidik sasaran peningkatan kapasitas tenaga kerja dan wanita. Bidikan ini selaras dengan visi Pengembangan Universitas Trunojoyo Madura Berbasis Klaster yang fokus pada pengembangan potensi Madura (6 sektor), yakni Garam, Pariwisata, Teknologi Tepat Guna, Jagung, Pendidikan, serta Tenaga Kerja dan Wanita.

Mengambil tema kegiatan "Pemanfaatan e-Commerce sebagai Peningkatan Mutu Sosial Tenaga
Kerja dan Wanita", diharapkan dari kegiatan pengabdian kepada masyarakat kali ini dapat memberikan stimulus bagi pertumbuhan ekonomi di wilayah Madura melalui pemberdayaan perempuan. Terlebih dalam perkembangan teknologi yang sudah masuk dalam setiap sendi kehidupan, salah satunya dalam perekonomian, dalam hal ini UMKM yang tidak hanya dilihat dari segi penciptaan lapangan pekerjaannya saja, melainkan juga sisi pemasaran.

Seiring dengan perkembangan teknologi informasi, e-commerce menjadi penting bagi setiap pelaku UMKM untuk dimanfaatkan. Keberadaan e-commerce terbukti tidak hanya dapat membantu memasarkan produk, namun juga meningkatkan jumlah wirausahawan baru yang berbekal e-commerce. Hal ini tentu pada akhirnya akan meningkatkan kualitas tenaga kerja dan wanita, utamanya bagi ibu rumah tangga warga Kelurahan Rongtengah Sampang Madura.

\section{METODE PENELITIAN}

Pengabdian pada Masyarakat yang diselenggarakan pada 6 Mei 2017 ini dilaksanakan dalam bentuk pelatihan pemasaran menggunakan $e$ commerce bagi ibu-ibu anggota PKK Kelurahan Rongtengah Kecamatan Sampang Kabupaten Sampang, Madura. Adapun metode yang digunakan dalam pelaksanaan pengabdian ini adalah dengan Pemaparan (ceramah), praktik penugasan dan tanya jawab. 
Pelaksanaan kegiatan

Pengabdian kepada Masyarakat Program Studi Pendidikan Informatika menyasar peserta ibu-ibu PKK Kelurahan Rongtengah Kecamatan Sampang Kabupaten Sampang, sebanyak 70 orang.

\section{Profil Mitra}

Kelurahan Rongtengah masuk dalam wilayah administrasi Kecamatan Sampang Kabupaten Sampang. Penduduk berjumlah 7.826 jiwa (3.772 laki-laki, 4.054 perempuan) (BPS Kabupaten Sampang, 2017). Kelurahan Rongtengah termasuk kelurahan dengan jenis tanah kering dan masuk dalam wilayah dataran rendah $(2,25$ MDPL), dengan luas wilayah 1,33 $\mathrm{KM}^{2}$. Kelurahan Rongtengah terdiri atas 6 Rukun Warga (RW) dengan 23 Rukun Tetangga (RT). Kelurahan ini masih memiliki 117 keluarga miskin, berdasarkan Surat Keterangan Miskin (SKM) yang diterbitkan.

Pemilihan

Kelurahan

Rongtengah sebagai mitra dalam kegiatan Pengabdian ini sangat sesuai dengan visi Universitas Trunojoyo Madura dalam rangka pengembangan wilayah Madura. Hal ini selaras pula dengan Rencana Strategis (Renstra) Dinas Koperasi dan Usaha Kecil Menengah Kabupaten Sampang 2013-2018 yang mengarahkan visinya pada terwujudnya pengembangan koperasi dan UKM yang maju dan inovatif berbasis kemitraan (Dinas Koperasi dan UKM Kabupaten Sampang, 2013).

\section{HASIL DAN PEMBAHASAN}

Pengenalan e-Commerce dan Market Place

Sesi pelatihan pemanfaatan $e$ commerce dimulai terlebih dahulu dengan mengenalkan pada peserta mengenai e-commerce dan Market Place. e-commerce merupakan istilah yang digunakan untuk menyebut suatu kegiatan perdagangan melalui sistem elektronik seperti internet ataupun televisi (). Hingga tahun 2017, sudah banyak situs-situs yang tergolong dalam Market Place. Namanama seperti Lazada, Tokopedia, elevenia, bukalapak, blibli, JD.id, Shopee serta masih banyak sederet nama lainnya, merupakan pelaku penyedia jasa perdagangan online.

Tabel 1. Jumlah Pengunjung Marketplace

\begin{tabular}{clr}
\hline No & $\begin{array}{c}\text { Nama Market } \\
\text { Place }\end{array}$ & $\begin{array}{c}\text { Jumlah } \\
\text { Pengunjung }\end{array}$ \\
\hline $\mathbf{1}$ & Lazada & 49.000 .000 \\
$\mathbf{2}$ & Tokopedia & 36.666 .667 \\
$\mathbf{3}$ & Elevenia & 32.666 .667 \\
$\mathbf{4}$ & Blibli & 27.000 .000 \\
$\mathbf{5}$ & Bukalapak & 25.666 .667 \\
$\mathbf{6}$ & Matahari Mall & 18.666 .667 \\
$\mathbf{7}$ & Alfacart & 16.000 .000 \\
$\mathbf{8}$ & JD.id & 3.666 .667 \\
$\mathbf{9}$ & Bhinneka & 3.166 .667 \\
\hline Sumber:
\end{tabular}

Sumber: www.cnnindonesia.com [diakses pada 11 November 2017] 
Ariesta Kartika Sari ${ }^{1}$, Wanda Ramansyah ${ }^{2}$, Puji Rahayu Ningsih ${ }^{3}$, Medika Risnasari ${ }^{4}$, Muchamad Arif ${ }^{5}$, Sigit Dwi Saputro ${ }^{6}$, Muhamad Afif $^{2}$ Effindi ${ }^{7}$ /Aksiologiya: Jurnal Pengabdian Kepada Masyarakat. Vol.1, No.2, Agustus 2017 Hal 151- 155

\section{Top Performing Online Consumer Goods Retailers in Indonesia}

\begin{tabular}{|l|c|c|c|c|c|c|c|}
\hline & Total Digital & Mobile (000) & Desktop (000) & $\begin{array}{c}\text { Total Minutes } \\
\text { (MM) }\end{array}$ & Total Views (MM) & $\begin{array}{c}\text { Avg. Minutes per } \\
\text { View }\end{array}$ \\
\hline 1 & Lazuada.co.id & 21,235 & 15,864 & 8,107 & 526 & 552 & 1 \\
\hline 2 & Blibli.com & 15,556 & 13,837 & 2,651 & 635 & 422 & 1.5 \\
\hline 3 & Tokopedia.com & 14,401 & 13,006 & 2,217 & 1,548 & 326 & 4.7 \\
\hline 4 & Elevenia.co.id & 12,872 & 9,535 & 5,130 & 438 & 285 & 1.5 \\
\hline 5 & MatahariMall.com & 12,520 & 11,516 & 1,879 & 410 & 516 & 0.8 \\
\hline 6 & Shopee.co.id & 11,301 & 10,872 & 763 & 2,169 & 136 & 16 \\
\hline 7 & Bukalapak.com & 10,407 & 8,971 & 2,203 & 459 & 193 & 2.4 \\
\hline 8 & Zalora.co.id & 9,052 & 8,636 & 813 & 396 & 493 & 0.8 \\
\hline 9 & Qoo10.co.id & 7,689 & 7,641 & 123 & 76 & 91 & 0.8 \\
\hline 10 & Blanja.com & 5,823 & 5,673 & 327 & 81 & 88 & 0.9 \\
\hline
\end{tabular}

Sumber: https://business.idntimes.com/economy/yoshi/pertumbuhan-e-commerce-indonesia-1/full [diakses pada 11 November 2017]

\section{Workshop Penjualan menggunakan Market Place}

Shopee mengklaim diri sebagai market place mobile-platform pertama di Asia Tenggara dan Taiwan yang menawarkan transaksi jual beli online yang menyenangkan, gratis, dan terpercaya melalui telepon genggam.

Sistematika kegiatan pengabdian

Cerita tentang bagaimanakah penerapan, foto kegiatan, materi yang dibahas, pertanyaan yang muncul atau kendala yang dialami oleh peserta dalam menggunakan aplikasi.

Materi (Pengantar Pemasaran Online, Shopee, Tokopedia)

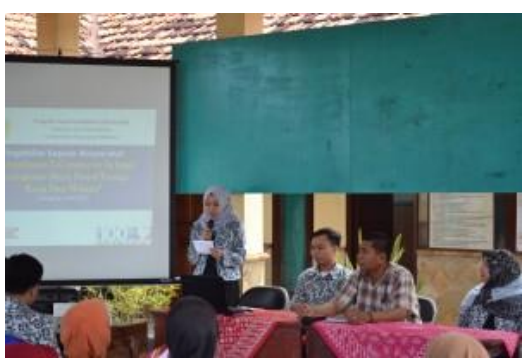

(a)

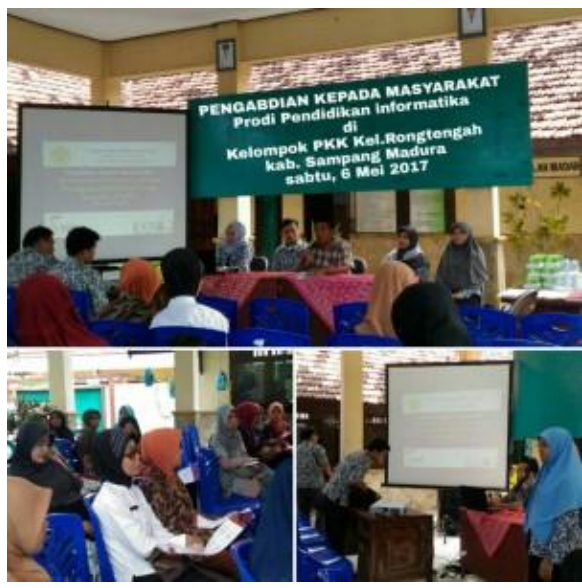

(b)

Gambar 4. Dokumentasi Pelaksanaan Pelatihan 
Ariesta Kartika Sari ${ }^{1}$, Wanda Ramansyah ${ }^{2}$, Puji Rahayu Ningsih ${ }^{3}$, Medika Risnasari ${ }^{4}$, Muchamad Arif ${ }^{5}$, Sigit Dwi Saputro ${ }^{6}$, Muhamad Afif Effindi ${ }^{7}$ /Aksiologiya: Jurnal Pengabdian Kepada Masyarakat. Vol.1, No.2, Agustus 2017 Hal 151-155

\section{SIMPULAN}

Melalui

kegiatan

Pengabdian Masyarakat ini, Program Studi Pendidikan Informatika Universitas Trunojoyo Madura melihat adanya potensi bagi perkembangan UMKM dalam menggunakan e-commerce dan Marketplace bagi perkembangan ekonomi yang pada akhirnya akan didapatkan peningkatan mutu sosial tenaga kerja dan wanita. Serangkaian kegiatan pelatihan yang dilaksanakan dalam kegiatan Pengabdian Masyarakat ini menunjukkan bahwa peserta memiliki pemahaman materi dan potensi untuk mengembangkan usaha.

\section{DAFTAR PUSTAKA}

Ahmadi, Candra \& Dadang Hermawan. 2013. EBusiness \& E-Commerce. Edisi 1. ISBN : 978-979-292319-3. Yogyakarta: ANDI.

Badan Pusat Statistik Kabupaten Sampang. 2017. Kecamatan
Sampang dalam Angka 2017. Sampang: BPS Kabupaten Sampang.

Dinas Koperasi dan UKM Kabupaten Sampang. 2013. Rencana Strategis Dinas Koperasi dan Usaha Kecil Menengah 2013-2018. Sampang: Dinas Koperasi dan Usaha Kecil Menengah Kabupaten Sampang.

Li, Yue dan Martin Rama. 2015. Firm Dynamics, Productivity Growth, and Job Creation in Developing Countries: The Role of Micro-and Small Enterprises. The World Bank Research Observer Volume 30 Number 1 February 2015 pp 3-38.

Laudon, Kenneth C.; Guercio Traver, Carol . 2014. E-commerce. business. technology. society. ISBN 978-013302444-9. 10th edition. Pearson. .

Wicaksono, Y. 2008. Panduan Praktis Buka Usaha dengan Modal Laptop. Jakarta: Elex Media Komputindo. 